\title{
Forage Yield and Silage Quality of Intercropped Maize+Soybean With Different Relative Maturity Cycle
}

\author{
Vanderson Vieira Batista ${ }^{1}$, Paulo Fernando Adami ${ }^{1}$, Laercio Ricardo Sartor ${ }^{1}$, Magali Floriano Da Silveira ${ }^{1}$, \\ André Brugnara Soares ${ }^{2}$, Karine Fuschter Oligini ${ }^{2}$, Diego Kwiecinski ${ }^{1}$, Michael Luiz Ferreira ${ }^{1}$, \\ Douglas Camana ${ }^{1}$, Cleverson Luiz Giacomel ${ }^{1} \&$ Amanda Cassu da Fonseca $^{1}$ \\ ${ }^{1}$ Technologic University of Paraná, Dois Vizinhos, Paraná, Brazil \\ ${ }^{2}$ Technologic University of Paraná, Pato Branco, Paraná, Brazil \\ Correspondence: Vanderson Vieira Batista, Technologic University of Paraná, Dois Vizinhos, PR, Brazil. Tel: \\ 55-46-999-000-618. E-mail: vandersonvbatista@hotmail.com
}

Received: August 15, 2018

doi:10.5539/jas.v10n12p249
Accepted: September 16, 2018

Online Published: November 15, 2018

\begin{abstract}
The success of maize+soybean intercrop depends on the correct synchronism between species phenological stages at the silage point. Due to it, the experiment was carried out to evaluate maize+soybean intercrop forage yield and silage quality using crops with different maturity cycle combination. The experiment used a randomized complete block design with a $2 \times 3$ factorial scheme. Treatments consisted of two maize hybrids (1: P1630YHR-early cycle and 2: middle cycle P30F53VYHR) and two soybean cultivars (P95R51-maturity cycle of 5.1; TMG7062-maturity cycle of 6.2) and one control represented by maize monocrop. Silage harvesting was performed when maize had reached 2/3 milk line stage. Intercropping soybean into maize did not affect its biomass yield. Both soybean cultivars present compatible cycles for ensiling together with maize hybrids, since they were in phenological stages from R5.3 to R7 by the time maize was at its optimum stage for ensiling. There was interaction between species for the soybean biomass yield. Maize hybrid P30F53 produced higher biomass yield than P1630 what also resulted in higher amount of total crude protein yield. Intercrop P1630-P95R51 produced $458 \mathrm{Kg} \mathrm{ha}^{-1}$ of crude protein more than maize monocrop. Maize+soybean intercropping system results in higher silage crude protein percentage and yield per area $\left(\mathrm{Kg}\right.$ of $\left.\mathrm{CP} \mathrm{ha}^{-1}\right)$.
\end{abstract}

Keywords: acid detergent fiber, animal feed, crude protein, dry mass, forage yield

\section{Introduction}

Maize silage is an important source of feed, particularly in the Brazilian dairy industry. The important traits of maize silage include high yield and high metabolisable energy, although, it has low protein content (Millner et al., 2005). In the other hand, soybean (Glycine $\max$ (L.) Merr.) is an important high-quality protein source for human and animal nutrition. It is mainly grown for grain and oil production, however, research have been showing its potential to be intercropped with maize (grow both species together at the same time and the same piece of land) (Sánchez et al., 2010).

Indeed, although not practiced in Brazil, maize+soybean intercrop is becoming more and more popular worldwide. Previous studies have documented that maize+soybean intercrop systems result in better environmental sources use efficiency for plant growth and thus stable yields when compared to monocrop system due to interspecific complementarily, facilitation and competition (Li et al., 2013; Latati et al., 2016).

Many studies have been reporting that intercropping soybean into maize did not affected maize biomass yield, showing similar or even higher values, what also resulted in silage with higher crude protein content (Oliveira et al. 2016; Sánchez et al., 2010; Stella et al., 2016). Higher radiation use efficiency (RUE) (Liu et al., 2017; Gao et al., 2010; Baghdadi et al., 2016) and better soil use (Baghdadi et al., 2016; Yang et al., 2017) of intercrop versus monocrop support these results and turn out in better land equivalent ratio (LER) (Gao et al., 2010; Martin et al., 1998).

Most studies on intercropping have focused on its resource utilization (water, light, nutrients) (Liu et al., 2017), and plant arrangement (density, number or rows) (Sánchez et al., 2016), however, the determination of an 
optimum plant maturity cycle between maize and soybean and its yield potential is a major agronomic goal in intercrop systems.

The selection of an appropriate maturity cultivar of soybean is important for the success of the intercrop. Earlier maturing varieties may have set seeds and their leaves will be senescing by the time maize is at its optimum stage for ensiling, while, late maturing cultivars may not have grain filled, what may reduce its crude protein contribution for the silage. According to Leonel et al. (2008), soybean should be in R7 stage at the moment maize is ready to be ensilaging.

Furthermore, these cultivars are influenced by the environment (soil conditions, latitude, altitude, etc.) and must be adapted to the region where it is going to be used, and present compatible cycles with maize. It was hypothesize that the presence of soybean as intercrop with maize will positively influence plant biomass yield and silage quality in relation to maize monocrop. Moreover, it was expected to find higher biomass yield for the maize hybrid with longer cycle, which also would fit better with longer soybean maturity cycle.

The objective of this research was to test two cultivars of maize and soybean with different maturity cycles to determine which is the best arrangement between these two species when grown as intercrops to produce high-quality silage.

\section{Material and Methods}

\subsection{Study Area}

Field experiment was carried out (2016/2017 summer growing season) at the Federal Technologic University of

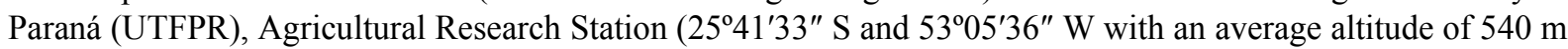
and a maximum slope of 3\%) southern of Brazil. According to the Köppen classification, the climate is Cfa (Alvares et al., 2013).

Soil at the experimental site is classified as a Clayey Oxisol. Chemical properties of the experimental soil area were determined before the start of this study in the 0.0-0.1 and 0.1-0.2 m soil layer, with the following results: $\mathrm{pH}\left(\mathrm{CaCl}_{2}\right) 5.6$ and 5.5; organic matter (OM) 46.2 and $30.8 \mathrm{~g} \mathrm{~kg}^{-1} ; \mathrm{P}$ (Mehlich1) 26.5 and $19.7 \mathrm{mg} \mathrm{dm}^{-3} ; \mathrm{K} 84.1$ and $35.2 \mathrm{mg} \mathrm{dm}^{-3}$, cation exchange capacity of 9.7 and $8.8 \mathrm{cmol}_{\mathrm{c}} \mathrm{dm}^{-3}$ and base saturation 71.5 and $66.6 \%$ respectively.

\subsection{Experimental Design}

This experiment was conducted from September 2, 2016 to February 22, 2017. The experiment used a randomized complete block design with a $2 \times 3$ factorial scheme. Treatments consisted of two maize hybrids (1: P1630YHR-early cycle and 2: middle cycle P30F53VYHR) and soybean cultivars (1: P95R51-relative maturity 5.1; 2: TMG7062-relative maturity 6.2 and 3: without soybean represented by maize monocrop) resulting in six treatments in the combination of these factors.

Treatment combinations were assigned to a split plot design in a randomized complete block with four replications. Corn hybrids were randomly assigned to the main plots while the soybean cultivars were randomly allocated to the subplots. Crops were sown as sole maize (M-2 hybrids) and four arrangements of maize and soybean intercropping 1 row maize to 1 row soybean. Intercropped maize was $60 \mathrm{~cm}$ from maize to maize and $30 \mathrm{~cm}$ from maize to soybean. The experimental plot size was of $60 \mathrm{~m}^{2}(3 \mathrm{~m} \times 20 \mathrm{~m})$.

Both maize and soybean varieties were resistant to herbicide glyphosate (RR2). Soybean cultivars have great branch potential and indeterminate growth habit. Moreover, TMG7062-IPRO Intacta RR2 PROTM has been genetically modified and express a endotoxin that allows the soybean plant to protect itself against the main caterpillars species (PROTM) and tolerance to Phakosphera pakirizi, a rust disease, having also a longer cycle (125 to 135 days to relative maturity-RM) (Tropical Breeding and Genetics, 2017) than the P95R51 (cycle of 115 to 125 days to RM). Corn hybrids (single-cross hybrid) used in the study stands out with high productive potential and are highly responsive to management. Are considered excellent options for grain and silage production and have a recommended seed rate positioning of 65,000 to 70,000 plants ha ${ }^{-1}$ (P30F53) and 70,000 to 80,000 plants ha ${ }^{-1}$ (P1630) (Dupont Pioneer, 2017). Maize seeds were treated with imidacloprid (2.6 g a.i. $\mathrm{Kg}^{-1}$ seed) and thiodicarb (7.9 g a.i. $\mathrm{Kg}^{-1}$ seed).

\subsection{Experiment Management, Sample Collection and Measurement}

Black oat (Avena strigosa) was used as prior crop and it was desiccated with glyphosate [(1.100 $\mathrm{g} \mathrm{ha}^{-1}$ of active ingredient (ai)] 21 days before intercrop establishment. On 09/02/2016, intercrop of maize+soybean was sown simultaneously with the aid of a precision planter with seed disc distribution configured with smooth cuts disk, fertilizer plow rod type and seed furrow double disc type set at $30 \mathrm{~cm}$ from each other in a pantograph system. A 
New Holland ${ }^{\circledR}$ tractor, model TT3840, $4 \times 2$ with a maximum power of $41 \mathrm{~kW}(55 \mathrm{hp})$ at 2,400 rpm with wheel tires was used to pull the seed drill at a constant speed of $4 \mathrm{~km} \mathrm{~h}^{-1}$. Maize seed discs had 28 holes, while soybean seed discs had 90 holes $(90 / 28=3.2$ soybean seed to each maize seed). Seed drill regulation was set up to sow 70.000 maize seeds ha ${ }^{-1}\left(4.2\right.$ seeds linear $\left.\mathrm{m}^{-1}\right)$ and soybean seed stand was a consequence $\left(225.000\right.$ seeds ha $\left.^{-1}\right)$ of it.

Mineral fertilization in the maize planting furrow consisted of 11 and $80 \mathrm{~kg} \mathrm{ha}^{-1}$ of $\mathrm{N}$ and $\mathrm{P} 2 \mathrm{O} 5$, respectively (366 kg ha ${ }^{-1}$ of $\mathrm{N}_{-} \mathrm{P}_{2} \mathrm{O}_{5}-\mathrm{K}_{2} \mathrm{O}$ fertilizer mixture 03-22-00). Potassium was broadcast using potassium chloride $\left(\mathrm{KCl}\right.$ with $60 \%$ of $\left.\mathrm{K}_{2} \mathrm{O}\right)$ at $185 \mathrm{Kg} \mathrm{ha}^{-1}$ at the sowing day. Nitrogen was applied as urea $(45 \%$ of $\mathrm{N})$ at the rate of $180 \mathrm{~kg}$ of $\mathrm{N} \mathrm{ha}^{-1}$. Half of the $\mathrm{N}$ required dosage was applied two weeks after sowing (09/19/2016) and the remaining half was applied six weeks after sowing (10/14/2016), all by manually side placement along the rows. Weed control was achieved by applying glyphosate on September 23 and October 08 at a rate of 1.400 and 1.200 $\mathrm{g} \mathrm{ha}^{-1}$ of a.i respectively.

Fungicide application was done at maize VT stage (pre-silking) with a systemic fungicide of ready mixture containing Protioconazol $\left(175 \mathrm{~g} \mathrm{~L}^{-1}\right)+$ Trifloxistrobina $\left(150 \mathrm{~g} \mathrm{~L}^{-1}\right)$ at a dose of $72+61 \mathrm{~g}$. i. a ha ${ }^{-1}$. Along with the fungicide, vegetable oil was added at a dose of $0.5 \mathrm{~L} \mathrm{ha}^{-1}$ and spray volume of $150 \mathrm{~L} \mathrm{ha}^{-1}$. Fungicide was applied with a self-propelled sprayer.

Corn and soybean intercrops were harvested at the same time considering $1 / 3$ of kernel milk line to black layer maturity, which happened 109 and 116 days after its emergence respectively for hybrid P1630 and P30F53. At that point, phenological stage of soybean cultivars was determinated. The evaluations were performed in 10 randomized plants by experimental unit, in a visual way, being considered as the stage of the crop, the one in which the majority of the plants were found.

At harvest time, final stand of maize (FSM) and soybean plants (FSS) (plants ha ${ }^{-1}$ ) were determined, counting the number of corn and soybean plants from each EU, being the values extrapolated to hectare.

Sample area considered the experimental unit two central rows ( 1 of corn and 1 of soybean) $5 \mathrm{~m}$ long, totaling a sample area of $6 \mathrm{~m}^{2}$. Plants were harvested by hand cutting the plants at $25 \mathrm{~cm}$ above the soil surface. They were weighed to determine maize (MGBY) and soybean green (SGBY) biomass yield. Then, plant samples of both crops of each experimental unit (EU) were ground separately on a forage harvester coupled to a tractor with an average particle size of 0.5 to $1.5 \mathrm{~cm}$. In addition, whole plant samples were weight fresh and sub-samples (300 g) were placed in paper bags, weighed and oven-dried at $65^{\circ} \mathrm{C}$ for at least 72 hours until constant weight to determinate its dry matter content. Forage DM yield was calculated from the fresh and dry weights of respective components listed above to determinate maize and soybean dry matter yield (MDMY and SDMY) and it sum resulted in the total dry matter yield (TDMY).

Total fresh and dry matter forage yield was calculated by adding maize and soybean values and data is showed in $\mathrm{kg} \mathrm{ha}^{-1}$. Moreover, dry matter per plant of maize (DMPM) and soybean (DMPS) (g) were determined dividing the plant total dry matter by its population. Furthermore, the percentage of soybean dry matter in the silage (PSS) was determined by the formula PSS $=\mathrm{SDMY} \times 100 / \mathrm{TDMY}$.

Samples of corn and soybean plants that had previously been collected and ground separately were grouped into the corresponding experimental units. Amount of maize and soybean were taken, respecting the proportion of the field biomass production between maize and soybean. This biomass was mixed for total homogenization and samples of $3 \mathrm{~kg}$ was packed compactly into Laboratory silos made of PVC pipes, measuring $100 \mathrm{~mm}$ in diameter, $600 \mathrm{~mm}$ in length, with average density of $600 \mathrm{~kg} \mathrm{~m}^{-3}$. The silos were sealed at the time of ensiling, with PVC caps fitted with 'Bunsen' type valves. The silos were opened after 60 days of the ensiling.

Upon the opening of the silos, the material was homogenized and extracted for further analysis. At the time, determination of $\mathrm{pH}$ was carried out using a $\mathrm{pH}$ meter in accordance with the methodology described by Silva \& Queiroz (2002). Samples collected (300 g) after the opening of the silos were placed in paper bags, weighed and oven-dried at $55{ }^{\circ} \mathrm{C}$ for at least 72 hours until constant weight to determinate its dry matter content. The pre-dried samples were ground in a 'Willey' type mill with a $1 \mathrm{~mm}$ mesh sieve, and the samples taken to the Bromatological Analysis Laboratory of the UTFPR.

Further analysis of dry matter, ashes (\%) (Silva \& Queiroz, 2002), neutral detergent fiber (NDF), acid detergent fiber (ADF) (\%) were determinated by the methodology described in the Ankon (2009) manual. Silage crude protein (SCP) $\left(\mathrm{g} \mathrm{kg}^{-1}\right)$ analyzes were performed by quantifying the $\mathrm{N}$ present in the samples, with the total $\mathrm{N}$ being determined in Kjeldhal semi-micro steam distillation methodology Tedesco et al. (1995). By multiplying SCP values by TDMY data, total crude protein yield (TCPY) $\left(\mathrm{Kg} \mathrm{ha}^{-1}\right)$ production of the crops was determined. 


\subsection{Statistical Analysis}

The data obtained was subjected to analysis of variance through the SISVAR 5.6 software (Ferreira, 2008), and when it presented significance for the ' $\mathrm{F}$ ' test, mean was compared through the Tukey test at a $5 \%$ probability. Soybean cultivars phenological stages are described along the text.

\section{Results and Discussion}

\subsection{Weather Conditions}

Total precipitation of $551 \mathrm{~mm}$ observed from September 2 to December 31 was well distributed along the experimental period, being September the period of lower rain (55 mm along the month), although, maize plants germinate well and showed good initial plant development. According to Aguilar and López-Bellido (1996), maize hybrids of medium-cycle requires 400 to $700 \mathrm{~mm}$ of water in its complete cycle when grown for grain. By that, it is inferred that rainfall was sufficient for the good development of the plants in the experimental period. Thus, maximum and minimum temperature recorded during the field study period were 27.4 and $16.9{ }^{\circ} \mathrm{C}$, respectively (Figure 1).

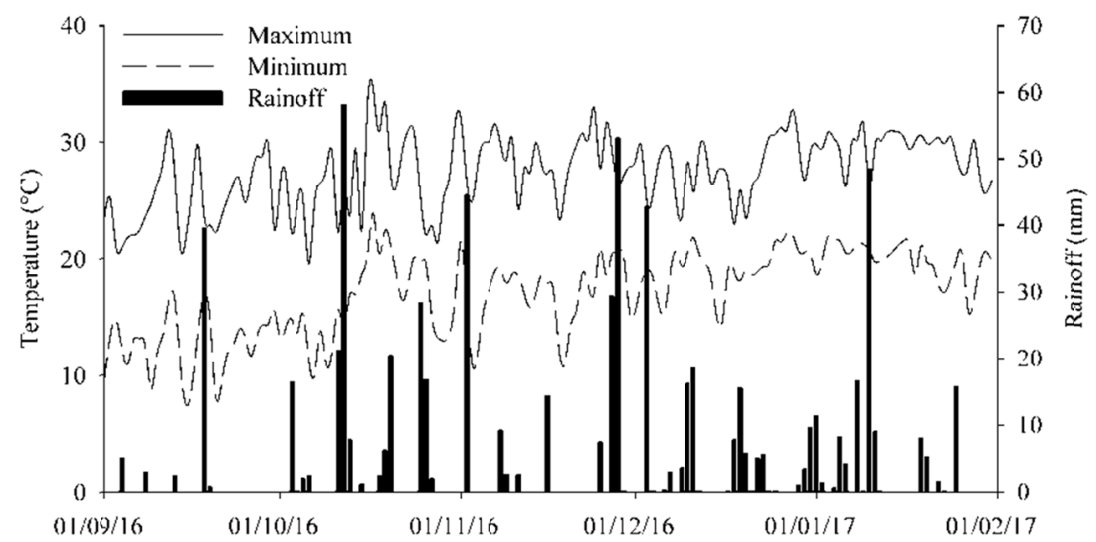

Figure 1. Maximum, minimum temperature and rainfall. UTFPR, Dois Vizinhos, Paraná, Brazil (2018)

\subsection{Phenological Stages of Soybean Cultivars}

By that time, soybean TMG7062 had reached the phenological stage R5.3 (26 to 50\% of grain filling), and soybean cultivar P95R51 had reached phenological stage R6 (full grain in one of the four upper nodes on the main stem) for the P1630 maize hybrid. For the P30F53 hybrid, TMG7062 and P95R51 had reached the phenological stage R6 and R7 (beginning of maturation-a pod with mature staining on the main stem) respectively.

The advance of reproductive stage changes the nutritional value of whole-plant soybean silage increasing crude protein as grain filling occurs (Dias et al., 2010). Evangelista et al. (2003) emphasize that when determining the correct time to harvest soybean for silage, it is necessary to combine grain filling stage and leaf retention to reach best silage quality and yield. In this context, Keplin (2004) reports that when silage is performed before R5 and latter than R7 stage, there is a reduction in the percentage of soybean crude protein. Moreover, Leonel et al. (2008) also reported that the right phenological stage of soybean plants to obtain silage with better quality is R7.

Evaluating soybean dry matter accumulation along phenological stages, Piana at al. (2017a) reported that soybean cultivars (CD 2610 IPRO and CD 2611 IPRO) reached the highest rate of mass increment 95 and 97 days after its emergence, respectively, in stage R5.5 (75 to 100\% grain filling). Moreover, Teodoro et al. (2015) points out that the highest rate of soybean dry mass accumulation occurs at the R6 stage.

Regarding to the soybean plant nitrogen content, Piana et al. (2017b) report that 80 days after its emergence, grains represent the soybean most important component and that grain $\mathrm{N}$ content increases up to 100 days after its emergence, remaining stable until the end of the cycle. The researchers point out that there are variations in the amount of biomass and nitrogen content in soybean plants throughout its cycle, but in general, the maximum accumulation occurs between R5 to R7 phenological stages.

In this context, it is possible to infer that both evaluated soybean cultivars present compatible cycles for ensiling together with maize hybrids, since they were in stages from R5.3 to R7, being at or very near to the point of 
maximum accumulation of dry mass and nitrogen content of the plant. Thus, when selecting a soybean cultivar for intercropping with corn, the cultivars that yield the highest in monocrop can be assumed to yield the highest when intercropped. Moreover, optimally higher biomass yields for later maturing soybean varieties seem to be the major factor contributing to higher protein yields in intercrops.

\subsection{Analysis of Variance (ANOVA)}

Table 1 shows the mean square values for the variables analyzed, with the respective level of significance.

Table 1. Mean square values of corn hybrids and soybean cultivars with distinct cycles, grown in a intercrop for silage. UTFPR, Dois Vizinhos, Paraná, Brazil (2018)

\begin{tabular}{|c|c|c|c|c|c|}
\hline & Df & FEM & MGBY & & MDMY \\
\hline Replications & 3 & $6,743,174.994450^{\text {ns }}$ & 7,009, & $000^{\text {ns }}$ & $2,194,401.375000^{\mathrm{ns}}$ \\
\hline Maize (M) & 1 & $32,851,306.840017^{*}$ & 2.2308 & $0009^{* *}$ & $127,471,113.375000^{* *}$ \\
\hline Soybean (S) & 2 & $787,057.925937^{\mathrm{ns}}$ & 8,088, & $667^{\text {ns }}$ & $3,401,042.625000^{\mathrm{ns}}$ \\
\hline$M \times S$ & 2 & $3,145,908.728204^{\mathrm{ns}}$ & 8,334, & $667^{\text {ns }}$ & $2,026,003.875000^{\mathrm{ns}}$ \\
\hline \multirow[t]{2}{*}{ Residue } & 15 & $6,871,222.111693$ & 16,051 & 3333 & $2,085,276.741667$ \\
\hline & Df & FES & SGBY & & SDMY \\
\hline Replications & 3 & $399,117,654.850256^{\mathrm{ns}}$ & 955,04 & $33^{\mathrm{ns}}$ & $36,118.597222^{\mathrm{ns}}$ \\
\hline Maize (M) & 1 & $6,386,986.470150^{\mathrm{ns}}$ & 28,512 & $1667 * *$ & $2,810,557.041667 * *$ \\
\hline Soybean (S) & 2 & $7.01727310^{\mathrm{e}}+0010^{* *}$ & 45,761 & $5000 * *$ & $3,894,682.541667 * *$ \\
\hline$M \times S$ & 2 & $54,006,041.232050^{\mathrm{ns}}$ & $7,633,3$ & $667 * *$ & $703,052.541667 * *$ \\
\hline \multirow[t]{2}{*}{ Residue } & 15 & $174,892,788.123006$ & 436,52 & & 52.937 .263889 \\
\hline & Df & TGBY & TDMY & & DMPM \\
\hline Replications & 3 & $12,731,268.930556^{\mathrm{ns}}$ & 1,894, & $111^{\mathrm{ns}}$ & $145.428537^{\mathrm{ns}}$ \\
\hline Maize (M) & 1 & $1.77213439^{\mathrm{e}}+0009^{* *}$ & 90,889 & $1667 * *$ & $21,835.871637 * *$ \\
\hline Soybean (S) & 2 & $21,474,300.791667^{\mathrm{ns}}$ & 476,63 & $00^{\mathrm{ns}}$ & $908.259784^{\mathrm{ns}}$ \\
\hline $\mathrm{M} \times \mathrm{S}$ & 2 & $28,474,482.791667^{\mathrm{ns}}$ & 4,731, & $667^{\mathrm{ns}}$ & $908.259784^{\mathrm{ns}}$ \\
\hline \multirow[t]{2}{*}{ Residue } & 15 & $18,225,363.863889$ & 2,059 & 778 & 616.399444 \\
\hline & Df & DMPS & PSS & $\mathrm{pH}$ & Ashes \\
\hline Replications & 3 & $0.543033^{\mathrm{ns}}$ & $1.120937^{\mathrm{ns}}$ & $0.003966^{\text {ns }}$ & $28.568840^{\mathrm{ns}}$ \\
\hline Maize (M) & 1 & $113.804904 * *$ & $100.833106^{* *}$ & $0.045503 * *$ & $69.524998^{\mathrm{ns}}$ \\
\hline Soybean (S) & 2 & $148.583366^{* *}$ & $109.586117 * *$ & $0.009528^{\mathrm{ns}}$ & $8.368570^{\mathrm{ns}}$ \\
\hline $\mathrm{M} \times \mathrm{S}$ & 2 & $28.494542 * *$ & $25.288467 * *$ & $0.000023^{\text {ns }}$ & $23.412140^{\mathrm{ns}}$ \\
\hline \multirow[t]{2}{*}{ Residue } & 15 & 2.593874 & 1.495155 & 0.003387 & 14.053020 \\
\hline & Df & NDF & ADF & SCP & TCPY \\
\hline Replications & 3 & $36.392415^{\mathrm{ns}}$ & $10.986911^{\mathrm{ns}}$ & $10.622777^{\mathrm{ns}}$ & $16,759.593698^{\mathrm{ns}}$ \\
\hline Maize (M) & 1 & $7.927826^{\mathrm{ns}}$ & $0.504151^{\mathrm{ns}}$ & $201.313646^{*}$ & $398,046.298089 * *$ \\
\hline Soybean (S) & 2 & $3.174360^{\mathrm{ns}}$ & $4.594612^{\mathrm{ns}}$ & $361.224159 * *$ & $157,350.545446^{*}$ \\
\hline $\mathrm{M} \times \mathrm{S}$ & 2 & $48.599259^{\mathrm{ns}}$ & $19.348340^{\mathrm{ns}}$ & $104.061314 *$ & $99,501.550493^{\mathrm{ns}}$ \\
\hline Residue & 15 & 30.410155 & 9.273851 & 23.457967 & $31,127.183099$ \\
\hline
\end{tabular}

Note. * Significant at the $\mathrm{p} \leq 0.05$ level. ${ }^{*}$ Significant at the $\mathrm{p} \leq 0.01$ level. ${ }^{\mathrm{NS}}$ Nonsignificant at the $\mathrm{p}>0.05$ level. FEM = Final stand of maize plants; MGBY = maize green biomass yield; MDMY = maize dry matter yield; FES = Final stand of soybean plants; SGBY = soybean green biomass yield; SDMY = soybean dry matter yield; $\mathrm{TGBY}=$ total green biomass yield; TDMY $=$ total dry matter yield (maize+soybean); DMPM $=$ dry matter per plant of maize; DMPS = dry matter per plant of soybean; PSS = percentage of soybean dry matter in the silage; $\mathrm{pH}=$ potential hydrogen; ashes; $\mathrm{NDF}=$ neutral detergent fiber; $\mathrm{ADF}=$ acid detergent fiber; $\mathrm{SCP}=$ Silage crude protein and total crude protein yield (TCPY).

It was noticed by the analysis of variance (ANOVA) $(\mathrm{p} \leq 0.05)$, significant interactions between maize hybrids and soybean cultivars to the: soybean green and dry matter yield (GSBY and SDMY), dry matter per soybean plant (DMPS), percentage of soybean into the dry matter biomass in silage (PSS) and silage total crude protein silage yield $\left(\mathrm{kg} \mathrm{ha}^{-1}\right)(\mathrm{TCP})($ Table 1$)$. 
There was effect of maize hybrids to the final stand of maize plants (FSM), maize green and dry matter biomass yield (MGBY and MDMY), total green and dry matter biomass yield (TGBY and TDMY), dry mass per maize plant (DMPM), silage potential hydrogen $(\mathrm{pH})$ and total crude protein (TCPY). Similarly, the use of soybean cultivars with different maturity cycles ad an influence on the final stand of soybean plants (FSS) and on the total crude protein yield (CPY), when comparing the factor alone (Table 1). For the variables ashes (\%), neutral detergent fiber (NDF), acid detergent fiber (ADF) (\%), no significance was observed for the evaluated factors (p $\leq 0.05$ ) (Table 1). There were also no differences between the blocks evaluated for any of the variables (Table 1).

\subsection{Plant Stand and Maize Biomass Yield}

On Table 2 it is possible to observe maize yield components (FSM, MGBY, MDMY and DMPM). Interestingly, the P30F53 was observed to be more productivity than P1630 for all these variables.

Table 2. Stand of plants and yield components of maize hybrids with distinct cycles intercropped with soybean for ensiling. UTFPR, Dois Vizinhos, Paraná, Brazil (2018)

\begin{tabular}{|c|c|c|c|c|c|}
\hline \multirow{2}{*}{ Maize/Soybean } & \multicolumn{5}{|c|}{ Final stand of maize (FEM) (plants ha ${ }^{-1}$ ) } \\
\hline & TMG7062 & P95R51 & Without soy & Mean & CV $(\%)$ \\
\hline P1630 & 63,690 & 64,285 & 63,690 & $63,888 \mathrm{~b}$ & \\
\hline P30F53 & 67,083 & 65,238 & 66,364 & 66,228 a & 4.02 \\
\hline Mean & 65,386 & 64,761 & 65,027 & 65,058 & \\
\hline \multirow{2}{*}{ Maize/Soybean } & \multicolumn{5}{|c|}{ Maize Green biomass yield (MGBY) $\left(\mathrm{Kg} \mathrm{ha}^{-1}\right)$} \\
\hline & TMG7062 & P95R51 & Without soy & Mean & $\mathrm{CV}(\%)$ \\
\hline P1630 & 46,062 & 48,957 & 47,261 & $47,427 \mathrm{~b}$ & \\
\hline P30F53 & 65,780 & 66,016 & 68,332 & $66,709 \mathrm{a}$ & 6.68 \\
\hline Mean & 55,921 & 57,487 & 57,797 & 57,068 & \\
\hline \multirow{2}{*}{ Maize/Soybean } & \multicolumn{5}{|c|}{ Maize dry matter yield (MDMY) $\left(\mathrm{Kg} \mathrm{ha}^{-1}\right)$} \\
\hline & TMG7062 & P95R51 & Without soy & Mean & CV $(\%)$ \\
\hline P1630 & 16,353 & 16,526 & 16,650 & $16,510 \mathrm{~b}$ & \\
\hline P30F53 & 19,899 & 21,262 & 22,196 & $21,119 \mathrm{a}$ & 7.71 \\
\hline Mean & 18,126 & 18,894 & 19,423 & 18,814 & \\
\hline \multirow{2}{*}{ Maize/Soybean } & \multicolumn{5}{|c|}{ Dry matter per plant of maize (DMPM) $(\mathrm{g})$} \\
\hline & TMG7062 & P95R51 & Without soy & Mean & CV $(\%)$ \\
\hline P1630 & 257.27 & 257.78 & 261.35 & $258.80 \mathrm{~b}$ & \\
\hline P30F53 & 297.02 & 326.05 & 334.32 & $319.13 \mathrm{a}$ & 8.03 \\
\hline Mean & 277.14 & 291.92 & 297.83 & 288.96 & \\
\hline
\end{tabular}

Note. Mean values followed by the different lower case letter in the column, differ by Tukey test $5 \%$. CV $=$ Coefficient of variation.

Corn hybrid P30F53 with medium-maturity cycle showed greater green biomass and dry matter yield compared to hybrid P1630 with early-maturity cycle (difference of 19.282 and $4.609 \mathrm{Kg} \mathrm{ha}^{-1}$, respectively). Vieira et al. (2016) and Assis et al. (2014) also reported differences in the biomass accumulation potential for maize, being the medium-maturity hybrids higher productive. One concern for production of short-season maize hybrids is that there is less time for leaf area production and for interception of photosynthetically active radiation (PAR) (Edwards et al., 2005).

Moreover, difference observed between hybrids may be associated with a greater susceptibility of P1630 to diseases such as Phaeosphaeria maydis and Helminthosporium turcicum. In this context, any reduction in leaf area or season-long light interception would likely result in decreased yield potential

Despite hybrid P30F53 had higher plant final stand $\left(2,340\right.$ plants ha $\left.^{-1}\right)$ than hybrid P1630, it is believed that this fact did not influence the results of biomass yield, since P1630 showed lower values of DMPM (61 g), evidencing that its plants had lower yield potential.

Maize biomass yield (silage) in the southern of Brazil typically produces between 40 to $50 \mathrm{tha}^{-1}$ of green material (Vieira et al., 2011). In this context, it was noticed that, even in the early cycle hybrid, yield is similar to 
what farmers have reported, although, it could be better. Higher plant population (mean final population: 63.888 plants $\mathrm{ha}^{-1}$ ), better $B t$ technology as offered today (LYH versus YH) and better disease management might allow higher yields. Moreover, early corn material allow earlier harvest and consequently anticipate second summer crop sowing, reducing frost risk and allowing higher yield to the productive system.

Intercropping soybean into maize did not affected maize biomass yield (Table 2). Similar results were reported by Alvarenga et al. (1998). Furthermore, Martin et al. (1998) studding the effect of soybean cultivars on maize-soybean intercrop biomass reported that none of them resulted in significantly lower biomass yields than the maize monocrop. Moreover, at the late soybean variety, land equivalent ratios of the intercrop shoot biomass yield revealed advantages of intercrops over monocrop of $21 \%$. Moreover, according to Sánchez et al. (2010), maize-soybean intercrop produced DM yields similar to those of monocropped maize due to higher maize yields in border rows adjacent to soybean.

Although, Oliveira et al. (1986) reported lower maize yield due to interspecific competition. In this way, good soil fertility associated with mineral fertilization, good crop management and wheater conditions, may have contributed to the development of the crop and, consequently, contributing to high biomass yields.

\subsection{Plant Stand and Soybean Biomass Yield}

It is observed on Table 3, that both soybean cultivars (TMG7062 or P95R51) showed lower biomass values when intercropped with maize P30F53. Taller plants, greater leaf area and higher biomass accumulation of the hybrid P30F53 (Table 2), possibly contributes to the shading of the soybean crop and, consequently, to the lower potential biomass accumulation of the soybean cultivars. Moreover, nowadays, the greatest challenge of Brazilian soybean farmers is a rust disease (Phakopsora pakirizi), that causes early fall of leaves and consequently lower productive potential. Thus, the disease inoculum pressure increase from December to January due to good climatic condition, what affect soybean shoot biomass yield when intercropped with maize P30F53.

Table 3. Final stand of plants and its yield components of soybean cultivars with distinct relative maturity intercropped with maize for silage. UTFPR, Dois Vizinhos, Paraná, Brazil (2018)

\begin{tabular}{|c|c|c|c|c|c|}
\hline \multirow{2}{*}{ Maize/Soybean } & \multicolumn{5}{|c|}{ Final stand of soybean (FSS) (plants ha ${ }^{-1}$ ) } \\
\hline & TMG7062 & P95R51 & Without soy & Mean & $\mathrm{CV}(\%)$ \\
\hline P1630 & 161,666 & 161,071 & 0.00 & 107,579 & \\
\hline P30F53 & 169,333 & 157,499 & 0.00 & 108,611 & 13.48 \\
\hline Mean & $164,999 \mathrm{~A}$ & $159,285 \mathrm{~A}$ & $0.00 \mathrm{~B}$ & 108,095 & \\
\hline \multirow{2}{*}{ Maize/Soybean } & \multicolumn{5}{|c|}{ Soybean green biomass yield (SGBY) $\left(\mathrm{Kg} \mathrm{ha}^{-1}\right)$} \\
\hline & TMG7062 & P95R51 & Without soy & Mean & $\mathrm{CV}(\%)$ \\
\hline P1630 & $6,108 \mathrm{Aa}$ & $4,897 \mathrm{Aa}$ & $0.00 \mathrm{Ba}$ & 3,668 & \\
\hline P30F53 & $3,340 \mathrm{Ab}$ & $1,124 \mathrm{Bb}$ & $0.00 \mathrm{Ba}$ & 1,488 & 28.05 \\
\hline Mean & 4,724 & 3,010 & 0.00 & 2,578 & \\
\hline \multirow{2}{*}{ Maize/Soybean } & \multicolumn{5}{|c|}{ Soybean dry matter yield (SDMY) $\left(\mathrm{Kg} \mathrm{ha}^{-1}\right)$} \\
\hline & TMG7062 & P95R51 & Without soy & Mean & $\mathrm{CV}(\%)$ \\
\hline P1630 & $1,886.00 \mathrm{Aa}$ & $1,438.00 \mathrm{Ba}$ & $0.00 \mathrm{Ca}$ & $1,108.00$ & \\
\hline P30F53 & $845.00 \mathrm{Ab}$ & $425.75 \mathrm{Bb}$ & $0.00 \mathrm{Ca}$ & 423.58 & 29.24 \\
\hline Mean & $1,365.50$ & 931.88 & 0.00 & 765.79 & \\
\hline \multirow{2}{*}{ Maize/Soybean } & \multicolumn{5}{|c|}{ Dry matter per plant of Soybean (DMPS) (g) } \\
\hline & TMG7062 & P95R51 & Without soy & Mean & $\mathrm{CV}(\%)$ \\
\hline P1630 & $11.76 \mathrm{Aa}$ & $9.00 \mathrm{Ba}$ & $0.00 \mathrm{Ca}$ & 6.92 & \\
\hline P30F53 & $5.08 \mathrm{Ab}$ & $2.61 \mathrm{ABb}$ & $0.00 \mathrm{Ba}$ & 2.56 & 31.65 \\
\hline Mean & 8.42 & 5.80 & 0.00 & 4.74 & \\
\hline
\end{tabular}

Note. Mean values followed by the different uppercase letter in the row and lowercase in the column, differ by Tukey test $5 \%$. CV $=$ Coefficient of variation.

It can be noticed in Table 3 that soybean green biomass yield (SGBY) was similar between cultivars for the P1630 hybrid. For the hybrid P30F53, cultivar TMG7062 stands out with $2.216 \mathrm{~kg} \mathrm{ha}^{-1}$ more than P95R51. 
Regarding to the dry matter yield, independent of the used maize hybrid, cultivar TMG7062 showed higher values than P95R51. Relative to the soybean weight per plant (DMPS), TMG7062 (11.76 g) showed plants heavier than P95R51 (9 g) at the P1630. For the P30F53, both cultivars presented similar values (Table 3).

These results show that between soybean cultivar, TMG7062 presents a higher productive potential of biomass in relation to P95R51, being more indicated for the intercrop system. Inox ${ }^{\circledR}$ technology which is a tolerance to rust (Phakopsora pakirizi) present on TMG7062 helped this cultivar to support disease pressure and reduce plants defoliation. Thus, shorter cycle of P95R51 stimulated its defoliation by the time maize was ensiled.

Sánchez et al. (2010) reported that maize+soybean intercropping caused a 62 to $70 \%$ decrease in soybean DM yield in relation to its monocrop. However, according to Gao et al. (2010), soybean plants can tolerate shade produced by maize plants in intercropped systems, and the author uses the land equivalent ratio to support his theory. Comparing maize monocrop with three rows of soybean alternated with one row of maize, land equivalent ratio for the intercrop was of 1.65. Moreover, the authors conclude that maize+soybean intercropping usually had greater radiation use efficiency (RUE) than sole cropping, which may account for the yield advantage of intercropping. Thus, (Liu et al., 2017), showed that photosynthetically active radiation (PAR) and radiation use efficiency (RUE) of intercropping systems (maize+soybean) were all higher than those of monocrop.

\subsection{Total Biomass Yield (Maize+Soybean)}

Table 4 shows the effect of maize hybrids on TGBY and TDMY. It is noticed that P30F53 showed higher biomass yield (17.186 and $3.892 \mathrm{~kg} \mathrm{ha}^{-1}$ of green and dry mass) than P1630.

Table 4. Total green biomass and dry matter yield of soybean cultivars intercropped with maize hybrids, both of distinct relative maturity groups. UTFPR, Dois Vizinhos, Paraná, Brazil (2018)

\begin{tabular}{llllll}
\hline \multirow{2}{*}{ Maize/Soybean } & \multicolumn{5}{c}{ Total green biomass yield (maize+soybean) $(\mathrm{TGBY})\left(\mathrm{Kg} \mathrm{ha}^{-1}\right)$} \\
\cline { 2 - 5 } P1630 & TMG7062 & P95R51 & Without soy & Mean & CV (\%) \\
\hline P30F53 & 52,170 & 53,855 & 47,261 & $51,095 \mathrm{~b}$ & \\
\hline Mean & 69,121 & 67,391 & 68,332 & $68,281 \mathrm{a}$ & 6.97 \\
\hline \multirow{2}{*}{ Maize/Soybean } & 60,646 & 60,623 & 57,797 & 59,688 & \\
\cline { 2 - 6 } & TMG7062 & P95R51 & Without soy & Mean & CV (\%) \\
\hline P1630 & 18,239 & 18,064 & 16,650 & $17,651 \mathrm{~b}$ & \\
P30F53 & 20,745 & 21,688 & 22,196 & $21,543 \mathrm{a}$ & 7.27 \\
Mean & 19,492 & 19,876 & 19,423 & 19,597 & \\
\hline
\end{tabular}

Note. Mean values followed by the different uppercase letter in the row and lowercase in the different column, differ by Tukey test $5 \%$. CV $=$ Coefficient of variation.

Soybean intercropped with maize P1630 tends to increase biomass yield. Lower final plant population (63.880 plants ha $\mathrm{a}^{-1}$ ), early relative maturity associated with lower leaf area index (LAI) and lower plants height allowed higher PAR and RUE to the soybean cultivars. In the other hand, P30F53 had higher plant population (66.228 plants $\mathrm{ha}^{-1}$ ) and taller plants, with greater LAI, what reduced the amount of light intercepted by soybean and its contribution to the total biomass production. Seems that in intercrop systems, it is necessary to reach an equilibrium between maize plant population and row arrangements aiming to allow soybean development and biomass accumulation.

Experiment mean green and dry matter biomass results (59.688 and $19.597 \mathrm{~kg} \mathrm{ha}^{-1}$ respectively) are higher than regional values reported in other studies (Vieira et al., 2011, 2016; Assis et al., 2014), showing that intercropping maize with soybean for silage presents a great potential as a system to be used by farmers. Furthermore, Oliveira et al. (1986) reported that maize-soybean intercropping resulted in higher DM yield in relation to the monocrop. Also, intercropping systems improved land use efficiency, once relative total yield (RTY) values of intercropping were higher than that of monocrop maize and soybean (Baghdadi et al., 2016).

Yield advantages from intercropping are often attributed to complementation between component crops in the mixture, resulting in a better total use of resources rather than growing crops separately. Furthermore, this 
complementation may be a result from both above and below-ground interactions between associated species (Latati et al., 2016).

Together these results provide important insights about maize+soybean intercrop, although, further studies need to be carried out, in order to identify the most efficient plant/row arrangement and population to be used to maximize intercrop yield and system adoption. Thus, nowadays, Phakopsora pakirizi disease management may also be a challenge in intercrop system, especially for maize hybrids with longer cycle.

\subsection{Bromatological Traits of Maize+Soybean Silage}

Table 5 shows the interaction between the evaluated factors for PSS. It was observed higher values of PSS at the silage with maize P1630, except for the monocrop (without soybean). Cultivar TMG7062 showed higher PSS than P95R51 (10.42 and 7.90\% respectively), when intercropped with hybrid P1630. However when intercropped with P30F53, it is observed that only the cultivar TMG7062 differs statistically from the treatment without soybean.

Table 5. Chemical-bromatological traits of silage from maize+soybean intercrop with different relativity maturity cycle. UTFPR, Dois Vizinhos, Paraná, Brazil (2018)

\begin{tabular}{|c|c|c|c|c|c|}
\hline \multirow{2}{*}{ Maize/Soybean } & \multicolumn{5}{|c|}{ Percentage of dry mass of soybean in silage (PSS) $(\%)$} \\
\hline & TMG7062 & P95R51 & Without soy & Mean & $\mathrm{CV}(\%)$ \\
\hline P1630 & $10.42 \mathrm{Aa}$ & $7.90 \mathrm{Ba}$ & $0.00 \mathrm{Ca}$ & 6.11 & \\
\hline P30F53 & $4.07 \mathrm{Ab}$ & $1.95 \mathrm{ABb}$ & $0.00 \mathrm{Ba}$ & 2.01 & 29.50 \\
\hline Mean & 7,25 & 4.93 & 0.00 & 4.06 & \\
\hline \multirow{2}{*}{ Maize/Soybean } & \multicolumn{5}{|c|}{ Potential hydrogen $(\mathrm{pH})$} \\
\hline & TMG7062 & P95R51 & Without soy & Mean & $\mathrm{CV}(\%)$ \\
\hline $\mathrm{P} 1630$ & 4.47 & 4.46 & 4.41 & $4.45 \mathrm{a}$ & \\
\hline P30F53 & 4.39 & 4.37 & 4.32 & $4.36 \mathrm{~b}$ & 1.34 \\
\hline Mean & 4.43 & 4.42 & 4.37 & 4.41 & \\
\hline \multirow{2}{*}{ Maize/Soybean } & \multicolumn{5}{|c|}{ Ashes $(\%)$} \\
\hline & TMG7062 & P95R51 & Without soy & Mean & $\mathrm{CV}(\%)$ \\
\hline $\mathrm{P} 1630$ & 3.93 & 3.44 & 3.59 & 3.65 & \\
\hline P30F53 & 3.94 & 4.13 & 3.89 & 3.99 & 10.62 \\
\hline Mean & 3.94 & 3.79 & 3.74 & 3.82 & \\
\hline \multirow{2}{*}{ Maize/Soybean } & \multicolumn{5}{|c|}{ Neutral detergent fiber (NDF) (\%) } \\
\hline & TMG7062 & P95R51 & Without soy & Mean & $\mathrm{CV}(\%)$ \\
\hline P1630 & 36.14 & 41.97 & 37.27 & 38.46 & \\
\hline P30F53 & 40.87 & 37.49 & 40.46 & 39.61 & 14.36 \\
\hline Mean & 38.50 & 39.73 & 38.86 & 39.03 & \\
\hline \multirow{2}{*}{ Maize/Soybean } & \multicolumn{5}{|c|}{ Acid detergent fiber (AFB) (\%) } \\
\hline & TMG7062 & P95R51 & Without soy & Mean & $\mathrm{CV}(\%)$ \\
\hline P1630 & 18.16 & 21.58 & 17.22 & 18.99 & \\
\hline P30F53 & 19.89 & 18.30 & 19.64 & 19.28 & 16.16 \\
\hline Mean & 19.03 & 19.94 & 1843 & 19,13 & \\
\hline \multirow{2}{*}{ Maize/Soybean } & \multicolumn{5}{|c|}{ Silage crude protein $(\mathrm{SCP})\left(\mathrm{g} \mathrm{Kg}^{-1}\right)$} \\
\hline & TMG7062 & P95R51 & Without soy & Mean & $\mathrm{CV}(\%)$ \\
\hline P1630 & $104.02 \mathrm{Aa}$ & $107.94 \mathrm{Aa}$ & $89.95 \mathrm{Ba}$ & 100.63 & \\
\hline P30F53 & $100.35 \mathrm{Aa}$ & $94.11 \mathrm{ABb}$ & $90.07 \mathrm{Ba}$ & 94.84 & 4.72 \\
\hline Mean & 102.18 & 101.02 & 90.01 & 97.74 & \\
\hline \multirow{2}{*}{ Maize/Soybean } & \multicolumn{5}{|c|}{ Total crude protein yield (TCPY) $\left(\mathrm{Kg} \mathrm{ha}^{-1}\right)$} \\
\hline & TMG7062 & P95R51 & Without soy & Mean & $\mathrm{CV}(\%)$ \\
\hline P1630 & 1,900 & 1,952 & 1,494 & $1,782 \mathrm{~b}$ & \\
\hline P30F53 & 2,076 & 2,039 & 2,004 & $2,040 \mathrm{a}$ & 8.87 \\
\hline Mean & $1,988 \mathrm{~A}$ & $1,995 \mathrm{~A}$ & $1,749 \mathrm{~B}$ & 1,911 & \\
\hline
\end{tabular}

Note. Mean values followed by the different uppercase letter in the row and lowercase in the column, differ by Tukey test $5 \%$. CV $=$ Coefficient of variation. 
According to Stella et al. (2016), the amount of soybean in silage is an important factor that must be taken into account, since it can affect quality of silage. The lower PSS reported for the P95R51 intercropped with maize P30F53 is mainly explained by plant defoliation due to rust disease.

Regarding to potential hydrogenous $(\mathrm{pH})$, values ranged from 4.36 and 4.45 for the P30F53 and P1630 respectively. Thus, although the silage presented different percentages of soybean in its composition, no effects of the legume on the $\mathrm{pH}$ of the silage were observed (Table 5). According to Kung and Shaver (2001), the final silage $\mathrm{pH}$ indicates the quality of the fermentation process and should be low enough (appropriate range from 3.8 to 4.2) to inhibit the growth of undesirable bacteria, such as those of the genus Clostridium.

The amount of ashes, NDF and ADF of silage were not influenced by the evaluated treatments, presenting average values of 3.82, 39.03 and $19.13 \%$ respectively (Table 5). Results corroborate with those observed by Sánchez et al. (2010) which only found lower fiber content, at the treatments with more than $10 \%$ of soybean into the silage.

According to Sánchez et al. (2010), soybean forage fiber concentration varied according to its phenological stage. Soybean cultivar harvested at phase R3 (beginning pod) presented NDF values equal to those of maize and higher ADF concentrations. In the other hand, when cultivar was harvested at phase R7 (beginning maturity), forage quality was better than maize, with lower NDF concentration and similar ADF values.

Martin et al. (1998) studding the effect of soybean cultivars on maize-soybean intercrop biomass reported that under intercropping, only the late soybean cultivars produced significantly higher protein yields than the maize monocrop. Intercrop shoot protein yield revealed yield advantages of intercrops over monocrop of $10 \%$. According to the authors, soybean with longer maturity cycle increased silage crude protein without affecting intercrop biomass yield and this result was attributed to higher percentage of leaves and minimal pods shattering at the time of intercrop silage harvest.

There was interaction between maize hybrids and soybean cultivars to the silage crude protein (Table 5). Silage from P1630 + TMG7062/P95R51 intercrop resulted in higher amount of crude protein (104.02 and $107.94 \mathrm{~g} \mathrm{Kg}^{-1}$, respectively) when compared to the maize monocrop (without soybean) $\left(89.95 \mathrm{~g} \mathrm{Kg}^{-1}\right)$. In the same way, silage from P30F53 + TMG7062 intercrop showed higher CP values $\left(100.35 \mathrm{~g} \mathrm{Kg}^{-1}\right)$ than the maize monocrop $(90.07 \mathrm{~g}$ $\left.\mathrm{Kg}^{-1}\right)$.

It is possible to infer that there is a close relation for SCP values with maize and soybean dry matter yield (Table 2 and 3). Treatments with lower maize biomass yield (P1630) allowed higher soybean development and yield which contributed to higher SCP in relation to maize monocrop. However, when maize biomass yield increased, as the case of hybrid P30F53, the soybean biomass reduced and only the cultivar TMG7062 presented the potential to differentiate from the treatment without soybean. These results show that the addition of soybean biomass to maize silage can increase the crude protein content of the silage, although, higher soybean biomass than observed is desired.

Pauli et al. (2017) evaluated maize silage crude protein content from 10 properties located near the experimental site and reported crude protein values from 54.9 to $91.0 \mathrm{~g} \mathrm{Kg}^{-1}$, being these values lower than those observed in the present study. According to Sánchez et al. (2010), crude protein content in maize+soybean silage from intercrops was 16 to $22 \mathrm{~g} \mathrm{~kg}^{-1}$ greater than in forage from monocropped maize.

When comparing maize hybrids, it is possible to observe that P30F53 produced higher amount of total crude protein than P1630, especially at the treatment without soybean, where this difference reaches $510 \mathrm{Kg} \mathrm{ha}^{-1}$ of crude protein. This difference was attenuated by the presence of soybean in the treatment with P1630, where intercrop with P95R51 produced $458 \mathrm{Kg} \mathrm{ha}^{-1}$ of crude protein more than maize monocrop. Increase silage protein content is important once it allows feed cost reduction and higher profit once crude protein derived from soybean meal is much more expansive (may cost to the Brazilian farmers up to US\$2.00 per crude protein kilogram) than crude protein derived forage production (may cost to the Brazilian farmers up to US\$ 0.50 per crude protein kilogram).

This higher productive potential of TCPY of the hybrid P30F53 is related to its higher values of biomass yield (Table 2). For the P1630 hybrid, maize+soybean intercropping system results in higher crude protein yield in the silage and per area, collaborating with other studies (Oliveira et al., 2016; Sánchez et al., 2010; Stella et al., 2016).

From the standpoint of chemical composition, the soybean plant can be added up to $50 \%$ in maize ensilage, resulting in improvements to the final product (Stella et al., 2016). According to Belel et al. (2014), improved 
forage production for agricultural industry is a key factor for current agricultural production, evidencing the need for studies in this area.

Although not widely practiced in Brazil, maize+soybean intercrop for silage appears to be an excellent environmentally sustainable method of producing high-quality silage. The results found in the present study corroborated with a number of other data already mentioned in the literature and further evidence the positive effects of maize+soybean intercrop system. Studies evaluating the crops intercropping system need to be carried out periodically, as the market for soybean cultivars and maize hybrids is constantly changing, with the use of new materials and the use of different technologies, aiming to assess and to identify better cultivars, plant arrangements, potential of fertilization reduction, etc. With that, maize+soyben intercrop may became more usual among farmers, once he already has the whole structure (seeds access, weed RR technology among crops, seeder and mechanical harvester adapted for the system) to adopt the system.

\section{Conclusion}

Intercropping soybean into maize did not affected maize biomass yield.

Soybean cultivars presented relative maturity phenological stages ranging from R5.3 to R7 by the time maize was at its optimum stage for ensiling showing to be compatible with the evaluated maize hybrids.

Maize hybrids of medium-maturity cycle as P30F53 presents a higher productive potential for ensiling, in relation to the early-maturity cycle P1630, resulting in higher total crude protein yield per area.

Soybean cultivar TMG7062 presents greater biomass yield than cultivar P95R51.

\section{References}

Aguilar M., \& López-Bellido L. (1996). Growth and yield of irrigated maize under Mediterranean conditions: The effect of cultivar and plant density. Cereal Research Communications, 4(24), 499-505.

Alvarenga, D. A., de Rezende, P. M., de Andrade, M. J. B., \& de Bastos Andrade, L. A. (1998). Consórcio soja-milho. v. efeito de sistemas de consórcio e de semeadura do milho. Ciência Rural, 28(2). https://doi.org/10.1590/S0103-84781998000200003

Alvares, C. A., Stape, J. L., Sentelhas, P. C., de Moraes, G., Leonardo, J., \& Sparovek, G. (2013). Köppen's climate classification map for Brazil. Meteorologische Zeitschrift, 22(6), 711-728. https://doi.org/10.1127/ 0941-2948/2013/0507

Ankon. (2009). Technology method 2: Rapid determination of oilfat utilizing high temperature solvent extraction. Macedon.

Assis, F. B., Basso, F. C., Lara, E. C., Raposo, E., Bertipaglia, L. M. A., \& de Oliveira, L. (2014). Caracterização agronômica e bromatológica de híbridos de milho para ensilagem Agronomic and chemical characteristics of hybrid corn to ensiling. Semina: Ciências Agrárias, 35(6), 2869-2882. https://doi.org/10.5433/1679-0359. 2014v35n6p2869

Baghdadi, A., Halim, R. A., Othman, R., Yusof, M. M., \& Atashgahi, A. R. M. (2016). Productivity, relative yield and plant growth of forage corn intercropped with soybean under different crop combination ratio. Legume Research, 39(4), 558-564.

Belel, M. D., Halim, R. A., Rafii, M. Y., \& Saud, H. M. (2014). Intercropping of corn with some selected legumes for improved forage production: A review. Journal of Agricultural Science, 6(3), 48. https://doi.org/10.5539/jas.v6n3p48

Dias, F. J., Cabreira Jobim, C., Soriani Filho, J. L., Bumbieris Junior, V. H., Poppi, E. C., \& Santello, G. A. (2010). Composição química e perdas totais de matéria seca na silagem de planta de soja. Acta Scientiarum: Animal Sciences, 32(1).

Dupont Pionner. (2017). Retrieved November 23, 2017, from http://www.pioneersementes.com.br

Edwards, J. T., Purcell, L. C., \& Vories, E. D. (2005). Light interception and yield potential of short-season maize (Zea mays L.) hybrids in the Midsouth. Agronomy Journal, 97(1), 225-234.

Evangelista, A. R., Rezende, P., \& Maciel, G. A. (2003). Uso da soja Glycine max (L.) Merril na forma de forragem. Lavras: Editora UFLA.

Ferreira, D. F. (2008). SISVAR: Um programa para análises e ensino de estatística. Revista Symposium, 6(2), 36-41). 
Gao, Y., Duan, A., Qiu, X., Sun, J., Zhang, J., Liu, H., \& Wang, H. (2010). Distribution and use efficiency of photosynthetically active radiation in strip intercropping of maize and soybean. Agronomy Journal, 102(4), 1149-1157. https://doi.org/10.2134/agronj2009.0409

Keplin, L. A. S. (2004). Silagem de soja: Uma opção para ser usada na nutrição animal (pp. 161-171). Simpósio Sobre Produção E Utilização De Forragens Conservadas, 2., 2004, Maringá. Anais... Maringá: Universidade Estadual de Maringá, UEM.

Kung, L., \& Shaver, R. (2001). Interpretation and use of silage fermentation analysis reports. Focus on Forage, $3(13), 1-5$.

Latati, M., Bargaz, A., Belarbi, B., Lazali, M., Benlahrech, S., Tellah, S., ... Ounane, S. M. (2016). The intercropping common bean with maize improves the rhizobial efficiency, resource use and grain yield under low phosphorus availability. European Journal of Agronomy, 72, 80-90. https://doi.org/10.1016/j.eja. 2015.09.015

Leonel, F. D. P., Pereira, J. C., Costa, M. G., Júnior, M., Lara, L. A., Sousa, D. D. P., \& Silva, C. J. D. (2008). Consórcio capim-braquiária e soja, produtividade das culturas e características qualitativas das silagens. Revista Brasileira de Zootecnia, 37(11), 2031-2040. https://doi.org/10.1590/S1516-35982008001100020

Li, L., Zhang, L., \& Zhang, F., (2013). Crop mixtures and the mechanisms of overyielding. In S. A. Levin (Ed.), Encyclopedia of Biodiversity (pp. 382-395). https://doi.org/10.1016/B978-0-12-384719-5.00363-4

Liu, X., Rahman, T., Yang, F., Song, C., Yong, T., Liu, J., ... Yang, W. (2017). PAR interception and utilization in different maize and soybean intercropping patterns. PloS One, 12(1), e0169218. https://doi.org/10.1371/ journal.pone. 0169218

Martin, R. C., Astatkie, T., \& Cooper, J. M. (1998). The effect of soybean variety on corn-soybean intercrop biomass and protein yields. Canadian Journal of Plant Science, 78(2), 289-294. https://doi.org/10.4141/ P97-030

Millner, J. P., Aver, R. V., \& Hardacre, A. K. (2005). The yield and nutritive value of maize hybrids grown for silage. New Zealand Journal of Agricultural Research, 48(1), 101-108. https://doi.org/10.1080/00288233. 2005.9513637

Oliveira, A. F., de Rezende, P. M., Ramalho, M., \& de Silva, A. P. (1986). Efeito da associação de cultivares de milho (Zea mays L.) e de soja (Glycine max (L.) Merril) no rendimento e valor nutritivo da forragem. Embrapa Milho e Sorgo-Artigo em periódico indexado (ALICE).

Oliveira, R. D., Silva, C. M. D., Mielezrski, F., Lima, J. S. B., \& Edvan, R. L. (2016). Harvest growth stages in soybean cultivars intended for silage. Acta Scientiarum: Animal Sciences, 38(4), 383-387. https://doi.org/ 10.4025/actascianimsci.v38i4.31837

Pauli, T., Hoinosk, M. E., Mascarelo, F. C., Di Domenico A. S., \& Fioreli, A. B. (2017). Avaliação Bromatológica de Amostras de Silagem de Milho de Propriedades Rurais de Dois Vizinhos-PR (pp. 247-249). IV Congresso de Ciência e Tecnologia da UTFPR-DV-I Mostra Científica da Pós-Graduação da UTFPR-DV.

Piana, S. C., Braccini, A. L., Batista, M. A., Pereira, L. C., Bianchessi, P. A., \& Dametto, I. B. (2017a). Acúmulo De Matéria Seca Em Soja Com Hábitos De Crescimento Diversificados. Anais Do Encontro Internacional De Produção Científica, 2017, Resumos ... Campinas, GALOÁ, 2018.

Piana, S. C., Braccini, A., Batista, M. A., Felber, P. H., Marteli, D. C. V., \& Takahashi, V. F. (2017b). Aferição Da Marcha De Absorção De Nitrogênio Em Soja Com Hábitos De Crescimento Diversificados. Anais Do Encontro Internacional De Produção Científica, 2017. Resumos ... Campinas, GALOÁ, 2018.

Sánchez, D. G. R., Silva, J. E., Gil, A. P., Corona, J. S. S., Wong, J. A. C., \& Mascorro, A. G. (2010). Forage yield and quality of intercropped corn and soybean in narrow strips. Spanish Journal of Agricultural Research, 3, 713-721. https://doi.org/10.5424/sjar/2010083-1269

Silva, D., \& Queiroz, A. D. (2002). Análise de alimentos: Métodos químicos e biológicos (3rd ed.). Viçosa: UFV, Impr. Univ.

Stella, L. A., Peripolli, V., Prates, Ê. R., \& Barcellos, J. O. J. (2016). Composição química das silagens de milho e sorgo com inclusão de planta inteira de soja. Boletim de Indústria Animal, 73(1), 73-79. https://doi.org/ 10.17523/bia.v73n1p73 
Tedesco, M. J., Gianello, C., Bissani, C. A., Bohnen, H., \& Volkweiss, S. J. (1995). Análises de solo, plantas e outros materiais (Vol. 174). Porto Alegre: UFRGS.

Teodoro, P. E., Ribeiro, L. P., Oliveira, E. P., Corrêa, C. C. G., \& Torres, F. E. (2015). Acúmulo de massa seca na soja em resposta a aplicação foliar com silício sob condições de déficit hídrico. Bioscience Journal, 31(1), 161-170. https://doi.org/10.14393/BJ-v31n1a2015-22283

Tropical Melhoramento e Genética. (2017). Retrieved September 24, 2018, from http://www.tmg.agr.br/cultivar/ tmg-7062-ipro

Vieira, A. F., Nunes, R. L. C., Torres, R. A., Dias, N. S., \& Oliveira, A. B. (2016). Avaliação Agronômica de Híbridos de Milho para Silagem em Baraúna, Região Semiárida Nordestina. Revista Brasileira de Milho e Sorgo, 14(2), 283-290. https://doi.org/10.18512/1980-6477/rbms.v14n2p283-290

Vieira, V. D. C., Moro, V., Farinacio, D., Martin, T. N., \& de Menezes, L. F. G. (2011). Caracterização da silagem de milho, produzida em propriedades rurais do sudoeste do Paraná. Revista Ceres, 58(4). https://doi.org/10.1590/S0034-737X2011000400009

Yang, F., Liao, D., Wu, X., Gao, R., Fan, Y., Raza, M. A., ... Du, J. (2017). Effect of aboveground and belowground interactions on the intercrop yields in maize+soybean relay intercropping systems. Field Crops Research, 203, 16-23. https://doi.org/10.1016/j.fcr.2016.12.007

\section{Copyrights}

Copyright for this article is retained by the author(s), with first publication rights granted to the journal.

This is an open-access article distributed under the terms and conditions of the Creative Commons Attribution license (http://creativecommons.org/licenses/by/4.0/). 